\author{
Шило Анастасія Петрівна, \\ аспірантка Київського університету \\ імені Бориса Грінченко \\ ORCID 0000-0001-6427-9766 \\ shilo93.ua@gmail.com
}

\title{
ЛАРИСА РУДЕНКО НА СЦЕНІ КИЇВСЬКОЇ ОПЕРИ: ВОКАЛЬНА ТВОРЧІСТЬ У ПОВОСННІ РОКИ (ЗА АРХІВНИМИ МАТЕРІАЛАМИ)
}

Мета роботи. У роботі висвітлюються вокальна творчість видатної української оперної співачки Лариси Архипівни Руденко (1918 - 1981) на основі професійної музичної критики та архівних матеріалів іiі Особового фонду, які зберігаються у Центральному державному архіві-музеї літератури і мистецтва України. Методологія дослідження грунтується на застосуванні таких методів як джерелознавчий, біографічний, аналітико-дескриптивний, ретроспективний, систематизації. Зазначені методи дають змогу розкрити та проаналізувати маловідомі сторінки виконавської діяльності Л. Руденко у повоєнні роки за допомогою матеріалів з архівних установ України. Наукова новизна дослідження полягає у використанні архівних матеріалів 50-60-х років XX століття, які засвідчують активну творчість Л. Руденко як солістки Київського оперного театру у повоєнні роки. Наведені архівні матеріали вперше вводяться у науковий обіг. У статті аналізуються вокальна діяльність Л. Руденко та іï роль у розвитку українського вокального мистецтва у повоєнні роки. Висвітлюються маловідомі сторінки біографії та виконавської діяльності відомої співачки. Розглядаються особливості роботи Л. Руденко над образами оперних героїнь. Характеризуються окремі творчі надбання виконавиці на прикладі іiі роботи над оперними партіями у провідних творах українських композиторів повоєнного часу. Висновки. Представлено оцінку вокальної діяльності Л. Руденко повоєнних років у висвітленні професійною музичною критикою та періодичною пресою. Доведено значний вплив творчої діяльності Л. Руденко на розвиток українського оперного мистецтва у повоєнні роки.

Ключові слова: архівні матеріали, вокальна творчість Лариси Руденко, вокальне мистецтво, українське оперне мистецтво у повоєнні роки, Київський оперний театр.

\section{Шило Анастасия Петровна, аспирантка Киевского университета имени Бориса Гринченко \\ Лариса Руденко на сцене Киевской оперы: вокальное творчество в послевоенные годы (по архивным материалам) \\ Цель статьи. В работе освещаются вокальное творчество выдающейся украинской оперной певицы} Ларисы Архиповны Руденко (1918 - 1981) на основе профессиональной музыкальной критики и архивных материалов ее Личного фонда, которые хранятся в Центральном государственном архиве-музее литературы и искусства Украины. Методология исследования основана на применении таких методов как источниковедение, биографический, аналитико-дескриптивный, ретроспективный, систематизации. Указанные методы позволяют раскрыть и проанализировать малоизвестные страницы исполнительской деятельности Л. Руденко в послевоенные годы с помощью материалов из архивных учреждений Украины. Научная новизна исследования заключается в использовании архивных материалов 50 - 60-х годов XX века, которые свидетельствуют активное творчество Л. Руденко как солистки Киевского оперного театра в послевоенные годы. Приведенные архивные материалы впервые вводятся в научный оборот. В статье анализируются вокальная деятельность Л. Руденко и ее роль в развитии украинского вокального искусства в послевоенные годы. Освещаются малоизвестные страницы биографии и исполнительской деятельности известной певицы. Рассматриваются особенности работы Л. Руденко над образами оперных героинь. Характеризуются отдельные творческие достижения исполнительницы на примере еe работы над оперными партиями в ведущих произведениях украинских композиторов послевоенного времени. Выводы. Представлена оценка вокальной деятельности Л. Руденко послевоенных лет в освещении профессиональной музыкальной критикой и периодической печатью. Доказано значительное влияние творческой деятельности Л. Руденко на развитие украинского оперного искусства в послевоенные годы.

Ключевые слова: архивные материалы, вокальное творчество Ларисы Руденко, вокальное искусство, украинское оперное искусство в послевоенные годы, Киевский оперный театр.

Shilo Anastasiya, postgraduate student of Kyiv University the name of Boris Grinchenko materials)

Larysa Rudenko on the stage of the Kyiv Opera: vocal creativity in the postwar years (on archival

The purpose of the article. The work highlights the vocal work of the prominent Ukrainian opera singer Larysa Arkhipivna Rudenko (1918 - 1981) on the basis of professional music criticism and archival materials of her Personal Fund, which are stored in the Central State Archive of the Museum of Literature and Art of Ukraine. The

(C) Шило А. П., 2019 
methodology of the research is based on the application of such methods as source-study, biographical, analyticaldescriptive, retrospective, systematization. These methods allow to reveal and analyze the little-known pages of the performance of L. Rudenko in post-war years with the help of materials from archival institutions of Ukraine. The scientific novelty of the study is the use of archival materials from the 50s and 60 s of the 20th century, which testify to the active work of L. Rudenko as soloists of the Kyiv Opera House in the post-war years. The above archival materials are first introduced into scientific circulation. The article analyzes the vocal activity of L. Rudenko and its role in the development of Ukrainian vocal art in the post-war years. The little-known pages of the biography and performances of the famous singer are covered. Features of L. Rudenko's work on the images of opera heroines are considered. Characterized by the individual achievements of the performer on the example of her work on opera parties in the leading works of Ukrainian composers of the postwar time. Conclusions. The estimation of vocal activity of L. Rudenko of post-war years in the coverage of professional musical criticism and periodicals is presented. The significant influence of L. Rudenko's creative activity on the development of Ukrainian operatic art in the postwar years has been proved.

Key words: archival materials, vocal work of Larysa Rudenko, vocal art, Ukrainian opera art in the postwar years, Kyiv opera theater.

Актуальність теми дослідження. Підсумком найвищих культурних досягнень є створення національних опер. Саме у жанрі опери відбиваються національна самобутність, світогляд народу та риси його характеру. Виникнення опери свідчить про високу культурну зрілість певної нації. Суспільне побутування оперного твору не мислиться без інституту оперного театру. В Україні перші державні оперні театри були створені у 20-ті роки XX століття (1925-1926).

Зі створенням інституту національного оперного театру українська опера набула можливості свого подальшого поступального розвою. Одним 3 таких інститутів в Україні стала Київська державна академічна опера (1926). Сьогодні Національний академічний театр опери та балету України ім. Т. Г. Шевченка - провідний центр оперного мистецтва нашої держави. Київська опера посідає чільне місце у становленні та розвитку національного вокального мистецтва. На сцені театру виступали відомі оперні виконавці, а саме Ф. Шаляпін, Л. Собінов, О. Петляш, М. ЛитвиненкоВольгемут, М. Донець, М. Донець-Тессейр, I. Козловський, О. Муравйова, 3. Гайдай, I. Паторжинський, Б. Гмиря, М. Гришко, Л. Руденко, Є. Чавдар, В. Третяк, А. Солов'яненко, Є. Мірошниченко, Д. Гнатюк, Г. Туфтіна, Г. Ципола, В. Лукянець, Л. Монастирська та інші.

Одним з важких періодів у розвитку Київського оперного театру стали воєнні та повоєнні часи. 15 червня 1941 року театр завершив свій черговий сезон виставою «Отелло» Дж. Верді. Велика група артистів Київського театру опери і балету восени була евакуйована спочатку до Уфи, а восени 1942-го - до Іркутська. Попри неймовірні труднощі перебування в евакуації, колектив театру не тільки зберіг постійний репертуар, а й ставив нові опери, зокрема, «Наймичку» М. Вериківського (Іркутськ, 1943) за мотивами творів Тараса Шевченка.

Окупаційна німецька влада теж не оминула своєю увагою Київський оперний театр. Під назвою Велика Київська опера він вже на початку 1942 року став систематично виставляти спектаклі, які відвідували представники окупаційної влади. Мистецтвознавець Ю. Станішевський у праці «Національний академічний театр опери та балету України імені Тараса Шевченка: Історія i сучасність» зазначає, що: «акторська трупа складалася переважно з українських артистів, серед яких були й солісти Київської опери М. Зубарєв, Г. Іващенко, Є. Циньов, О. Гродзинський, В. Пекарський, I. Шведов, О. Уляницька, Р. Окіпна, котрі не встигли виїхати з колективом столичного театру в евакуацію. На чолі художнього керівництва Київської Великої опери з 27 листопада 1941 року стояв відомий хормейстер і диригент $\mathrm{M}$. Тараканов, завдяки діяльності якого оперні постановки відзначалися досить високим музичним рівнем. У лютому 1942 року після того, як гестапівці дізналися, що дружина М. Тараканова єврейка і розстріляли іï, художню частину очолював німецький диригент В. Брюкнер. У театрі запанувала військова дисципліна, за найменше порушення суворого розпорядку можна було заплатити життям. Новий директор, плануючи втілення музичних драм Р. Вагнера, розширив оркестрову яму, збільшив склад симфонічного оркестру та хору, куди влилися студенти ліквідованої в січні 1943 року Музично-драматичної академії, рятуючись від масового відправлення до Німеччини» [7, 209].

Відомо про план київського підпілля щодо підриву будівлі театру під час оперної вистави. Саме в такий спосіб збиралися знищити верхівку офіцерського складу нацистів. Проте цей план здійснити не вдалося. Згодом, 2 травня 1943 р. центр Києва бомбардувала радянська авіація, зокрема Володимирську вулицю. В приміщення театру влучила авіабомба та, пробивши дах і підлогу в партері, де вбила чотирьох фашистських офіцерів, загрузла в піску, яким було заповнено цоколь, й не вибухнула. В цей час на сцені оперного театру лунала вистава «Лоенгрін», якою диригував 
жорстокий німецький диригент В. Брюкнер. Як свідчать учасники спектаклю, після недовгої перерви диригент примусив переляканих артистів продовжувати виставу та доспівати вагнерівську оперу.

Після значних пошкоджень театр потребував відновлень та реставрації.

Відразу після визволення Києва саме оперний театр було відремонтовано в першу чергу. Повернувшись із евакуації, київський оперно-балетний колектив розпочав свою діяльність на рідній сцені 28 жовтня 1944 року оперою «Наймичка» М. Вериківського, яка вперше прозвучала на українській сцені. Попри важкі повоєнні труднощі колектив швидко відновив свій репертуар. Підготовка оперних прем'єр поєднувалась із відновленням кращих спектаклів, створених до війни та в період евакуації. У повоєнні роки на київській оперній сцені поряд із уславленими співаками публіка почула майстерне виконання нового покоління вокалістів, серед яких Єлизавета Чавдар, Дмитро Гнатюк, Лариса Руденко. Отже, актуальність теми дослідження полягає у висвітленні вокальної творчості провідних українських співаків у повоєнні часи.

Аналіз досліджень і публікацій. Значна увага сучасними мистецтвознавцями приділяється проблемам національного оперного мистецтва, зокрема, українській вокальній школі $[1 ; 6 ; 7]$, історії вокального мистецтва [2] та вокально-виконавській творчості [3]. Творчому шляху Л. Руденко присвячені наукові праці Л. Грисенко [4], В. Кононенко і М. Мар'яненко [5], спогади В. Тольби [8]. Зокрема, Л.Грисенко у своїй монографії надає стислі відомості про життєвий і творчій шлях Л. А. Руденко. В. Кононенко і М. Мар'яненко у своїй роботі висвітлюють деякі подробиці біографії Л. Руденко, іiі навчання, а також представляють загальну характеристику іiї вокально-педагогічної діяльності. Проте цілісного аналізу творчої діяльності Л. Руденко у повоєнні роки на сьогодні не існує. Вагомими джерелами у дослідженні постаті Л. Руденко, ii життєвого і творчого шляху є матеріали українських архівних установ, а саме Центрального державного архіву-музею літератури та мистецтва України $[9 ; 10 ; 11 ; 12 ; 13]$.

Мета статті полягає у висвітленні вокальної творчості Лариси Руденко як солістки Київського оперного театру у повоєнні роки. Звідси постають завдання охарактеризувати творчу діяльність Л. Руденко під час війни, розглянути вокальну творчість Л. Руденко у провідних операх українських композиторів повоєнного часу, висвітлити особистість Л. Руденко через спогади ії сучасників та малознані факти архівних документів, які зберігаються у фонді Центрального державного архівумузею літератури і мистецтва України.

Виклад основного матеріалу. Лариса Руденко - одна з найобдарованіших учениць славетного педагога Олени Олександрівни Муравйової - розпочала свою виконавську діяльність напередодні війни. Після Всесоюзного конкурсу вокалістів 1938 року студентку IV курсу Київської консерваторії Л. Руденко без прослуховування було запрошено до Київського державного академічного театру опери та балету ім. Т. Шевченка. Дебютом співачки в театрі стала партія Поліни 3 опери П. Чайковського «Винова краля». В оперному театрі Л. Руденко в своїй роботі над вокальними партіями використовувала систему К. Станіславського, якою вона оволоділа під час навчання та використовувала в практичній роботі в Оперній студії при Київській консерваторії. Ця система допомагала їй у створенні реалістичних жіночих образів в оперних творах. Зокрема, працюючи над образами оперних героїнь, Л. Руденко починала з вивчення історичних подій, звичаїв народу, знання побутового дворянського етикету, модних тенденцій певної доби. Вона вчилася рухатися сценою і носити історичне вбрання. Все це, на думку співачки, повинно було підпорядковуватися створенню вокального образу $[4,12]$.

Готуючи партію Поліни з Л. Руденко, оперний режисер М. Смолич ставив перед співачкою завдання створити образ шляхетної дівчини XIX сторіччя. Згадуючи свою працю 3 Л. Руденко, М. Смолич підкреслював особливості вокальної партії: «Партія Поліни хоч невелика, але вокально складна, бо вимагає повного діапазону голосу (два октави), кантиленного вільного фразування, широкого розвиненого дихання, володіння рівним звуком по всьому регістру та гнучкою вокальною лінією» $[4,12]$. Він висував певні вимоги й стосовно сценічного втілення образу, адже виконавиця повинна дотримуватися шляхетної поведінки, притаманної панянці XIX сторіччя, а саме: «повинна була відповідати і їі зовнішня поведінка: стримані й благородні жести, рухи» $[4,12]$. М. Смолич підкреслював, що шляхетна манера героїні повинна відбиватися й у виконанні співачкою вокальної партії: «Звучання голосу повне, красиве, соковите, але без нагнітання і афектації. Фразування потрібне м'яке, без різких контрастів, нюансування звука - плавне, без різких змін» $[4,12]$. Молода співачка Л. Руденко прекрасно впоралась з цим складним завданням. Ї̈і дебют вдався на славу, після чого вона стала рівноправним артистом творчого колективу Київської опери.

Після успішного дебюту виконавиця почала готувати низку нових партій - Ольги («Євгеній Онєгін» П. Чайковського), Миловзора («Винова краля» П. Чайковського), Зібеля («Фауст» Ш. Гуно), 
Емілії («Отелло» Дж. Верді). Л. Руденко згадувала про роботу над сценою Дездемони та Емілії: «Хоч ця роль зовсім невелика за масштабом, але за змістом дуже важлива. Емілія відгукується на кожний порух душі, кожний нюанс в настрої Дездемони, намагається заспокоїти іiї, чимось зарадити. Тому і вокальна партія, і сценічна поведінка Емілії повинна бути дуже м'якою, тактовною, делікатною. Основне в її поведінці - велике співчуття до Дездемони, бажання полегшити іiі страждання» [5, 9]. Всі ці тонкі психологічні нюанси на сцені Ларисі Руденко допомагали втілити режисер М.Смолич та творчий взаємозв'язок з відомими оперними співачками 3. Гайдай та Н. Захарченко, які виконували партію Дездемони.

На початку війни разом з колективом театру Л. Руденко виїхала в евакуацію, спочатку до Уфи, а потім - до Іркутська. В ці роки співачка виступала у складі концертних бригад на фронтах, в шпиталях перед пораненими бійцями (в Уфі, Тулі, Калузі, Куйбишеві). Артистка не могла без хвилювання та співчуття згадувати виступи у шпиталях [9].

У повоєнні часи у репертуарі Київського оперного театру в одному ряду з класичними оперними творами постали опери сучасних українських композиторів Ю. Мейтуса («Молода гвардія», 1947), Г.Жуковського («Честь», 1947; «Перша весна», 1959), К. Данькевича («Богдан Хмельницький», 1951), Г. Майбороди («Милана», 1957; «Арсенал», 1960).

Одними 3 яскравих вокальних партій в українському оперному репертуарі стали партії Улі Громової («Молода гвардія») та Соломії («Богдан Хмельницький»). Образи цих героїнь стали одними 3 найкращих у репертуарі Лариси Руденко. У своєму інтерв'ю журналу «Радянська жінка» виконавиця підкреслила значення партії Соломії у своєму творчому доробку, пов'язуючи риси характеру цієї героїні з характером Улі Громової. Так, образ Соломії асоціювався в творчій уяві співачки 3 «сучасницями - кращими дочками радянського народу, які примножили славу своїх батьків, виявивши небачений в історії героїзм і мужність, захищаючи свою соціалістичну Батьківщину від ворожої фашистської навали» $[10,3]$. Водночас виконуючи партію Улі Громової, вона вбачала «в історичній біографії комсомолки-патріотки ії відважних предків» [10, 3$]$.

Образ Улі Громової став для співачки одним з найпроникливіших та близьких, адже у створенні цієї ролі Л. Руденко повністю покладалася на особисті життєві переживання. Співаючи арію «Люблю тебе, мій рідний краю», вона відтворювала щирі та зворушливі почуття своєї героїні до рідної землі, тим самим захоплюючи та переносячи глядача на рідні й самій виконавиці донецькі степи і простори. Дослідник українського музичного театру Ю. Станішевський дав високу оцінку Л. Руденко як виконавиці партії Улі Громової: «Тендітна темнокоса дівчина 3 вольовим сильним характером відкривала свою палку душу вже у схвильовано-емоційнії арії першої дії «Люблю тебе, мій степе, в ції дні». Ще виразніше вияскравлювались іiї внутрішня краса і мужність у сцені допиту» $[7,225]$.

Ще одна перлина репертуару видатної співачки Л. Руденко - образ Варки з опери «Перша весна» Г. Жуковського. Виконавиця зі всією уважністю підійшла до інтерпретації цього образу, адже він відрізнявся від попередніх. Варка до всього ставилася байдуже, легковажно та іронічно. Але вже 3 розвитком дії, поступово відбувається становлення характеру персонажу. Л. Руденко зуміла донести до слухача провідну думку твору: «Основний смисл життя - це чесна, самовіддана праця» $[4,38]$. Артистка доносить поклик героїні, яка усвідомлює, що «ніколи не треба втрачати віру в себе і ніколи не пізно обрати правильний шлях у житті» $[4,38]$.

Поціновувачі мистецтва Л. Руденко завжди з ентузіазмом та теплотою відгукувалися про творчість співачки. Підтвердженням цього $є$ багата кількість листів, які зберігаються у Центральному державному архіві-музею літератури і мистецтва України. «В Київській опері багато гарних співаків та співачок, але якось Ваш голос більше усіх мене хвилює та западає в душу», - писала А. Блюм, захоплюючись талантом та обдарованістю голосу Л. Руденко $[11,1]$. Професор О. М. Брагін пише в одному з листів: «Слухав по радіо твою Амнеріс - отримав велике задоволення. Вважаю, що ти зараз перше та єдине мец-сопрано!» $[12,2]$. Для митця велика пошана отримувати листи з такою вдячністю та відданістю. Це найкраща оцінка праці талановитої особистості.

Мистецтво Л. Руденко було завжди щирим, сердечним, «справжнім», що легко знаходило шлях до серця слухачів. За свою виконавську творчість співачка бачила лише позитивні реакції аудиторії на іiї виконання: захват, захоплення, співчуття, прихильність. Це співачка відчула вже під час концертів перед пораненими бійцями, для яких ії спів був як ковток повітря.

Народний артист УРСР С. Козак, колега по оперній сцені, підкреслював громадянську позицію Л. Руденко: «В особі Лариси Архипівни щасливо поєднується багато благородних рис, які висувають артистку в когорту славних діячів ... мистецтва» $[13,1]$. С. Козак у своєму інтерв'ю газеті «Вечірний Київ» надав характеристику сучасному артисту оперного театру: «Працюючи постійно над 
підвищенням своєї майстерності, над новими творами, виступаючи на сцені театру, артист має пам'ятати, що він громадянин [...] і тому все, чим живе народ, зрозуміле, близьке, хвилююче для митця» $[13,1]$. Він зазначив, що усі названі риси притаманні Л. Руденко.

Наукова новизна статті полягає у висвітленні вокальної творчості Л. Руденко як солістки Київського оперного театру у повоєнні роки на основі матеріалів іiі Особового фонду, який зберігається у Центральному державному архіві-музею літератури і мистецтва України. Використані в даній статті архівні матеріали, представлені публікаціями статей про творчу діяльність співачки в періодичній пресі. Приведені архівні документи вперше вводяться у науковий обіг.

Висновки. Підсумовуючи вищевикладене, слід зазначити, що все своє творче життя Л. Руденко присвятила Київському театру опери і балету ім. Т.Шевченка, на сцені якого вона понад 30 -ти років була провідною солісткою й виконала близько 50 оперних партій. Створюючи жіночі образи в українських операх композиторів-сучасників, Л. Руденко ніколи не вдавалася до зовнішніх показових ефектів та хизування виконанням технічних вокальних труднощів. Манера ії виконання була проста й щира. Л. Руденко зосереджувала свою увагу на внутрішньому змісті твору, змушуючи слухачів думати, переживати, радіти разом та вірити кожному ііі слову. Працюючи над вокальною партією, вона випрацьовувала не лише конкретний образ своєї героїні як такий, а створювала його в контексті драматургії даної опери. Це дозволяло слухачам не лише переживати долі іï героїнь, а й роздумувати над ними в процесі оперної дії. Виконання Л. Руденко жіночих образів надовго закарбовувалося в пам'яті слухачів. Співачці притаманні висока культура виконання, артистичність, природний голос, вміння виліпити цілісний вокальний образ у контексті оперної драматургії певного твору, детально вибудований сценічний малюнок ролі, цілковита єдність образного змісту вокальної партії з її зовнішнім втіленням.

У своїй вокальній творчості Л. Руденко відобразила традиції виконавського мистецтва свого вокального педагога О. Муравйової та продовжила і примножила своїми власними досягненнями як оперна співачка. Ці здобутки вона перенесла у свою подальшу педагогічну діяльність, виховавши плеяду оперних меццо-сопрано.

\section{Jimepamypa}

1. Гнидь Б. Виконавські школи України. Київ: НМАУ, 2002. 96 с.

2. Гнидь Б. Історія вокального мистецтва. Київ: НМАУ, 1997. 320 с.

3. Гребенюк Н. Є. Вокально-виконавська творчість: автореф. дис. на здобуття наук. ступеня д-ра мистецтвознавства: 17.00.03. Київ, 2000. -39 с.

4. Грисенко Л. Лариса Руденко. Київ: Музична Україна, 1978.

5. Кононенко В., Мар'яненко М. Лариса Архипівна Руденко. Київ, Мистецтво, 1963. - 35 с.

6. Лисенко І. Словник співаків України. Київ: Рада, 1997. - 354 с.

7. Станішевський Ю. Національний академічний театр опери та балету України імені Тараса Шевченка: Історія і сучасність. Київ: Музична Україна, 2002. - 736с .

8. Тольба В. Статті. Спогади. Київ: Музична Україна, 1986. - 156 с.

9. Центральний державний архів-музей літератури і мистецтва України, м. Київ. Ф. 120. Руденко Лариса. Грамоти.

10. Центральний державний архів-музей літератури і мистецтва України, м. Київ. Ф. 120. Руденко Лариса. Статті про творчість та рецензії на концерти за його участю. Оп. 1. Спр. 145. Арк. 3. Лариса Руденко // «Радянська жінка» - 1954.

11. Центральний державний архів-музей літератури і мистецтва України, м. Київ. Ф. 120. Руденко Лариса. Статті про творчість та рецензії на концерти за його участю. Оп. 1. Спр. 25. Арк. 1. А. Я. Блюм. Лист до Л. Руденко // Москва.

12. Центральний державний архів-музей літератури і мистецтва України, м. Київ. Ф. 120. Руденко Лариса. Статті про творчість та рецензії на концерти за його участю. Оп. 1. Спр. 24. Арк. 2. А. М. Брагін. Лист до Л. Руденко // Баку.

13. Центральний державний архів-музей літератури і мистецтва України, м. Київ. Ф. 120. Руденко Лариса. Статті про творчість та рецензії на концерти за його участю. Оп. 1. Спр. 148. Арк. 1. С. Козак Лариса Руденко // Вечірній Київ. - 1963. - 21 лютого.

\section{References}

1. Gnydy, B. (2002). Performing Schools of Ukraine. Kyiv: NMAU [in Ukrainian].

2. Gnydy, B. (1997). History of vocal art. Kyiv: NMAU [in Ukrainian].

3. Grebenyuk, N. E. (2000). Vocal-performing creativity: author's work. dis for obtaining sciences. Extended abstract of candidate's thesis. Kyiv: National Music Academy of Ukraine 2000 [in Ukrainian].

4. Grisenko, L. (1978). Larisa Rudenko. Kyiv: Muzychna Ukrayina [in Russian].

5. Kononenko, V. \& Maryanenko, M. (1963). Larysa Arkhipivna Rudenko. Kyiv: Mystetstvo [in Russian]. 
6. Lysenko, I. (1997). Dictionary of singers of Ukraine. Kyiv: Rada [in Ukrainian].

7. Stanishevsky, Y. (2002). National Academic Theater of Opera and Ballet of Ukraine named after Taras Shevchenko: History and Present. Kyiv: Musical Ukraine [in Ukrainian].

8. Tolba, V. (1986). Articles. Memoirs. Kyiv: Muzychna Ukrayina [in Russian].

9. Central State Archive-Museum of Literature and Art of Ukraine. F. 120. Rudenko Larisa. Articles about creativity and reviews of concerts with his participation. Nyemyenova-Lunts, M. (1939). Op. 1. Spr. 165. Ark. 1 «AllUnion vocal competition». Yzvestyya [in Russian].

10. Central State Archive-Museum of Literature and Art of Ukraine. F. 120. Rudenko Larisa. Articles about creativity and reviews of concerts with his participation. Lyakhov, V. \& Pohorzhelskyy, H. (1972). Op. 1. Spr. 143. Ark. 6. «Land of Talents». Za chest shakhtarya [in Russian].

11. Central State Archive-Museum of Literature and Art of Ukraine. F. 120. Rudenko Larisa. Articles about creativity and reviews of concerts with his participation. Ryazhskiy, O. (1972). Op. 1. Spr. 143. Ark. 2. «Larisa Rudenko». Hovoryt i pokazuye Moskva [in Russian].

12. Central State Archive-Museum of Literature and Art of Ukraine. F. 120. Rudenko Larisa. Articles about creativity and reviews of concerts with his participation. Serpilin, L. (1951). Op. 1. Spr. 167. Ark. 12. «The Queen of Spades». Performance of the Kiev Opera and Ballet Theater. Vechirniy Kyiv [in Russian].

13. Central State Archive-Museum of Literature and Art of Ukraine. F. 120. Rudenko Larisa. Articles about creativity and reviews of concerts with his participation. Kozak, S. (1963). Op. 1. Spr. 143. Ark. 1. «Artists and spectators - for». Komsomolets Ukrayiny [in Russian].

Стаття надійшла до редакції 04.11.2018 p. 